\title{
KONGHUCU DI KOREA KONTEMPORER DAN SUMBANGANNYA TERHADAP KERUKUNAN UMAT BERAGAMA DI INDONESIA
}

\author{
Dian Nur Anna \\ Dosen Fakultas Ushuluddin dan Pemikiran Islam \\ UIN Sunan Kalijaga Yogyakarta \\ Diterima 10 Maret 2013/Disetujui 15 Juni 2013
}

\begin{abstract}
Abtract
Confucianism is a minority religion in Korea and Indonesia, but the spiritual movement of Confucianism can be accepted by some religions and may also be practiced. This study aimed to uncover how did Koh Byong-ik on Confucianism in South Korea in the future and how was this contemporary contribution to religious harmony in Indonesia critical analysis. Results of this study indicated that a statistically Confucian minority turned out after a deep study, a dominating ideology Korea. Though a minority, they had the spiritual strength to embrace a religion. The Confucian doctrine turned out to support the harmony of religious life and this was the initial capital to strengthen brotherbood among religions.
\end{abstract}

Kata kunci: Konghucu, kerukunan, umat beragama

\section{Pendahuluan}

Konghucu itu dianggap sebagai agama rakyat dari Rakyat Korea, dan banyak orang menganggap bahwa Konghucu bukanlah sebuah agama. Dalam buku berjudul Confusian Traditions in East Asia Modernity : Moral Education and the Four Mini Dragons, Koh Byong-ok ${ }^{1}$ mencoba mengilustrasikan bagaimana Konhucu ${ }^{2}$ secara formal termasuk minoritas

${ }^{1}$ Koh Byong-ik , "Confucianism in Korea Kontemporer", dalam Tu WeyMing (ed) Confusian Traditions in East Asia Modernity : Moral Education and the Four Mini Dragons,(Cambridge, Massachusetts, London, England: Harvard University Press, 1996), h. $191-201$

${ }^{2}$ Kata yang penulis pakai untuk menyebut Kong $\mathrm{Hu} \mathrm{Cu}$. Kong $\mathrm{Hu} \mathrm{Cu}$ itu merupakan kumpulan kitab-kitab klasik yaitu ada 5 Kitab suci dan 4 buku yang dikumpulkan oleh Kung Fu-Tze (menurut tradisi 551-479 sebelum Masehi)(Cina: Guru Kung). Dia adalah filsuf Cina yang menyebarkan semangat pembaharuan dalam tata cara masyarakat Cina denagn menekankan bahwa baik kalangan bawahan masingmasing memiliki tempat tersendiri dalam susunan masyarakat. Di kepustakaan Barat dikenal dengan Konfusias (Confucius). Pandangan baru itu kemudian berkembang 
dapat menarik perhatian para pemeluk lain untuk mengikuti ajarannya. Menurut data statistik, jumlah Konghucu itu hanya $2 \%$ dari jumlah penduduk Korea. Hal ini menjadi sangat menarik dimana, ketika melakukan penyelidikan dengan interviw secara detile, ternyata 91,7\% Korea adalah Konghucu, meskipun mereka juga masih menganut agama yang lain.

Artikel ini menarik untuk dikaji dimana ajaran Kongucu itu diterima oleh orang Korea. Pada masa kontemporer ini, Konghucu menawarkan etika yang dapat diterima bukan hanya bagi orang yang tidak beragama, tetapi juga beberapa agama menerima konsep ajarannya da bahkan banyak yang mempraktekkannya. Seperti orang Buddha, Hindu, Kristen Protestan dan Kriste Katolik.

Dari fenomena ini, dapat ditarik benang merah, dimana Konghucu dapat dikategorikan ajaran yang dapat menyatukan bukan hanya intern para pemeluk agama Konghucu sendiri tetapi juga dari pemeluk agama lain. Manfaatnya adalah Konghucu ini dapat dijadikan tempat untuk membina kerukunan antar agama, karena Konghucu sangat terbuka bagi adanya agama lain. Tidak menjadi konflik ketika Konghucu bersentuhan dengan agama lain, tetapi antara agama dapat saling mengisi dan saling menguntungkan.

Kalau dihubungkan dengan Indonesia, jumlah Konghucu Indonesia hampir mirip dengan Korea dimana Konghucu di Indonesia kalau dibandingkan dengan pemeluk agama lain, itu termasuk minoritas. Dengan demikian, tidak menutup kemungkinan bahwa gerakan spiritual Konghucu dapat diterima oleh beberapa agama dan mungkin juga dapat dipraktekkan.

menjadi falsafah dasar agama Kong $\mathrm{Hu} \mathrm{Cu}$ atau Konfusianisme, yang sangst cocok untuk lapisan masyarakat bukan bangsawan dalam kekaisaran Cina. Pada jaman dinasti Sung (960 Masehi-1279), ajaran Kong Hu Cu mengalami pembaharuan berupa NeoKonfusianisme yang lebih menitikberatkan pada keharusan menuntut ilmu selain pada masalah rohaniah dan meditasi. Salah satu kepustakaan paling terpercaya tentang hidup dan ajaran K'ung Fu-Tze adalah kitab Lunyu (Percakapan dengan K'ung Fu Tze atau Konfusias). Hassan Shadily (Pimp. Redaksi), Ensiklopedia Indonesia 4, (Jakarta: Penerbit buku Ichtiar Baru-Van Hoeve, 1983), h. 1917. Ajaran Confucius dikuatkan oleh Mencius (Men-tze) seorang filsuf Cina yang hidup satu abat kemudian. Filsafat Confucius itu condong bersifat praktis dan duniawi. Mengenai Ajaran Confucius dapat dilihat dalam Analects yaitu ajaran-ajaran yang berisi kumpulan dari petuah-petuahnya yang menjadi bagian dari Sastra Klasik Cina. Harold H. Titus, dan Marilyn S. Smith, serta Richard T. Nolan, Pesoalan-persoalan Filsafat, alih bahasa H.M. Rasjidi, (Jakarta, Indonesia: Bulan Bintang, 1984), h. 484. 
Dalam tulisan ini peneliti ingin mengungkap bagaimana pendapat Koh Byong-ik tentang Konghucu di Korea Selatan pada masa kontemporer ini dan bagaimana sumbangannya terhadap kerukunan umat beragama di Indonesia.

Untuk mensistematikan pembahasan, tulisan ini dimulai dengan kehidupan keberagamaan orang Korea dan menerangkan problem komplek dari Konghucu, yaitu identifikasi Konghucu, warisan ajaran Konghucu, relevansi kepada modernitas, dan kemungkinan transformasi ke depan. Sebagai ilustrasi terakhir, penulis ingin mengungkapkan juga problem perkembangan masa depan gerakan spiritual Konghucu dan pengembangan dialog antar agama menuju terwujudnya kerukunan antar umat beragama khususnya di Indonesia.

\section{Kehidupan keberagamaan di Korea}

Di Asia Timur, Korea disebut sebagai negara yang sangat Konghucu. Banyak sekali nilai-nilai Konghucu ${ }^{3}$ dilaksanaakan di Korea. Sehingga banyak orang Korea melaksanakan tingkah laku menurut nilainilai dari faham Konghucu dan cara berfikirnya. Konghucu, kelompok yang keberadaannya menjadi minoritas, (800.000 dari 7,5 million atau 2 $\%$ dari jumlah penduduk-menurut data statistik yng dikeluarkan olah Menteri Kebudayaan dan Informasi sekitar tahun 1984) ini, ternyata telah menjadi ideologi yang dominan di Korea. ${ }^{4}$

Dalam bidang pendidikan ${ }^{5}$, ada etik Konghucu yang dimasukkan dalam kurikulum di Sekolah Dasar. Sekitar abat ke-19,

${ }^{3}$ Nilai-nilai universal dari Konghucu itu tetap ada dimanapun juga, tetapi dalam prakteknya itu berbeda karena disesuaikan dengan kondisi.

${ }^{4}$ Harold H. Titus, dan Marilyn S. Smith, serta Richard T. Nolan, Pesoalanpersoalan Filsafat, h. 192.

${ }^{5}$ Secara historis, kalas Yangban, sebagai pembawa tradisi Konghucu abad ke 4, mengalami perpecahan. Hal ini disebabkan oleh adanya perang di masyarakat, migrasi dan lain-lain. Sehingga, Tradisi Konghucu saat itu tidak dapat memecahkan problem pendidikan modern. Namun ditingkat bahwah, rakyat mempunyai kesempatan untuk belajar dan mengembangkan diri.

Hyanggo sebagai sekolah tradisi orang-orang Konghucu di ibukota dan propinsi dan sowon atau akademi private atau shu-yuan telah kehilangan fungsi dalam pendidikan. Sehingga tidak ada lagi berdoa, penyembahan kepada sesuatu yang disucikan. Kemudian Konghucu muncul pada level dasar dan dipraktekkan oleh masyarakat.

Meskipun wajah Konghucu telah terkoyak dan menghilang, masih ada beberapa organisasi yang tetap mempertahankan Konghucu sebagai acuannya, yaitu Songgyngwan dan byanggo. Songgyungwan sebagai pusat studi Konghucu tetap menjalankan ritual kepada Konfusius dengan musik kuno dan mengontrol byanggo. 
Upacara Konghucu menjadi model di Korea dan telah diatur oleh pemerintah pada tahun 1973. Seperti adanya upacara leluhur, upacara penguburan dan masa berkabung, garis keturunan telah dipraktekkan oleh masyarakat. Dari berbagai uraian di atas, orang Korea telah menjadi Konghucu.

Dari fenomena di atas, Konghucu ternyata menyimpan sesuatu yang menakjubkan, yang tidaklah sia-sia untuk diteliti. Dimana meskipun berdasarkan data statistik termasuk minoritas, ternyata etikanya dapat merambah pada aspek kehidupan. Dengan demikian, tidaklah diragukan, ketika ada penelitian yang secara intensif meneliti tentang agama Korea. Contohnya adalah penelitian yang difokuskan pada karakter agama orang Korea.

\section{Identifikasi Konghucu}

Yoon-Yi-hum seorang professor ilmu agama dari Universitas Nasional Seol melakukan penelitian untuk menganalisa karakter agama orang Korea. Dia menggunakan metode identifikasi konfensional. Dengan metode ini, ternyata menghasilkan gambaran yang berbeda seputar puncak agama di Korea. ${ }^{6}$ Langkahnya adalah dengan melakukan wawancara terhadap orang satu persatu dengan menyodorkan beberapa pertanyaan tentang keyakinan dan praktek Konghucu ${ }^{7}$ di masyarakat.

'Secara umum, sensus yang dilakukan pemerintah menunjukkan bahwa Kristen berjumlah 30\%, Budha $20 \%$ dan Konghucu 1\% dari jumlah penduduk di Korea Selatan.

${ }^{7}$ Pertanyaan seputar keyakinan ( dibagi menjadi 3 sampai 5 bagian, kemudian menjadi 20 bagian) adalah: tentang kesucian dan kepatuhan; tiga nilai utama dan 5 etik (san-kang wu-lun); kebajikan, keadilan, kehormatan dan kebijaksanaan (jen-i li-chin); perbaikan diri dan pengaturan keluarga (hsiu-shen ch'i-ching); pemujaan dari kebijaksanaan kuno dan manusia bijaksana; tidak melanggar tradisi; kepercayaan terhadap kebaikan manusia; dan kesucian dari 4 buku dan 5 Kitab Kuno (ssu-shu-wucing). Dari pertanyaan yang dilontarkan, banyak responden yang ragu-ragu menjawab dan tidak setulus hati, sehingga menghasilkan tendensi yang kabur. Mengenai kategori praktek (kemudian dibagi menjadi 13 kategori), kategori yang diukur adalah (a) praktek yang terhitung utama, yaitu upacara peringatan nenek moyang; kesucian ; dan perbedaan usia yang lebih tinggi. (b) praktek-praktek secara umum yaitu: hak anak sulung dan kebaikan dari warisan yang diambil dari bapak; ritual pemakaman nenek moyang secara teratur; tiga tahun hari berkabung untuk orang tua yang telah meninggal; pernyataan hormat kepada orang tua pada saat pernikahan; dan larangan endogamy. (c) partisipasi dalam aktivitas kelompok meliputi: upacara peringatan kepada nenek moyang; pertemuan suku-suku dan penambahan nama dari silsilah suku,; organisasi orang-orang Konghucu; aktivitas sekolah Konghucu local (hyanggyo). Responden ini kemudian diklasifikasi menjadi 4 nilai dari Konghucu, yaitu aktif, normal, batas atau 
Hasil dari penelitian ini menunjukkan bahwa orang beragama Katolik, Protestan, Buddha, ataupun orang yang tidak beragama sekalipun itu termasuk Konghucu. Mereka cenderung ke nilai-nilai Konghucu dan mempraktekkan secara baik. Orang yang tidak beragama dari 189 orang, ternyata yang mempraktekkan Konghucu ada 183 orang (96,8\%), sedangkan $90 \%$ dari Katolik dan 76,4 \% dari Protestan juga dipandang sebagai Konghucu. Hal ini senada dengan pernyataan dari Teolog Kristen yang menyatakan bahwa "Kekristenan kami adalah Konghucu dalam jubah Kristen" Dari 400 yang diwawancarai, ternyata ada $91,7 \%$ adalah termasuk pengikut Konghucu pinggiran. ${ }^{8}$

Hasil di atas merupakan karakteristik keberagamaan di Korea saat itu, meskipun hal ini tidak dapat dianggap benar untuk masa mendatang. Karena dunia akan berjalan terus, ada kemungkinan karakteristik keagamaan akan berubah juga. Ada 3 poin penting untuk mengevaluasi persoalan ini.' (1) Paham Konghucu telah mulai lenyap, tetapi nilai-nilai dan prakteknya masih tetap berjalan. Warisan Konghucu itu akan berkelanjutan tergantung kepada tingkah laku dari penduduk secara keseluruhan. (2) Konghucu relatif toleran terhadap orang lain. Alasannya adalah pada kenyataannya, Paham Konghucu disamping anggotanya tidak diorganisasikan, juga tidak mempunyai semangat misionaris untuk mengembangkan dirinya sendiri, dan yang tak kalah pentingnya adalah pelajaran moral yang humanis yang dapat diterapkan secara universal. Konghucu mentoleransi dan ditoleransikan dengan agama lain dan kemudian ini dapat diterima oleh agama lain. (3) Ajaran Konghucu tidak mengenai penyelamatan. Ketika orang merasa putus asa dan duka cita, mereka cenderung untuk mengusahakan diri kepada agama lain. Sehingga antara Konghucu dan agama lain seperti Kristen, Budha itu saling melengkapi dan tidak mengandung kontradiksi satu dengan yang lain.

Dengan demikian, Ajaran Konghucu yang telah dipraktekkan itu merupakan karakteristik keagamaan orang Korea. Itu merupakan warisan $^{10}$ yang tak ternilai harganya. Jika penduduk mempraktekkan ajaran Konghucu, maka warisan Konghucu itu akan berkelanjutan.

pinggiran dan luar, yang tergantung kepada kesepakatan komitmen kepada bagianbagian dalam kedua kategori tersebut.

${ }^{8}$ Harold H. Titus, dan Marilyn S. Smith, serta Richard T. Nolan, Pesoalanpersoalan Filsafat, h. 199.

${ }^{9}$ Harold H. Titus, dan Marilyn S. Smith, serta Richard T. Nolan, Pesoalanpersoalan Filsafat, h. 199-200.

${ }^{10}$ Aspek-aspek yang menyebabkan Budaya Cina terwariskan itu berhubungan dengan ajaran konghucu yang mementingkan ritual dan keharusan untuk menguasai 


\section{Warisan dan Modernisasi}

Dengan beralihnya generasi, warisan Konghucu mengalami penyusutan. Ada pengaruh baru yang tidak mendukung secara langsung tradisi Konghucu, melawan sesuatu yang menolak kedepan seperti nasionalisme yang menyelidiki identitas dalam tradisi dan warisan, serta perpecahan moral yang diakibat oleh industrialisasi di Era Modern ini. Berdasar fenomena di atas, ada anggapan bahwa Konghucu adalah penghalang utama untuk modernisasi dan pembangunan.

Sekarang ada anggapan yang berkembang dimana warisanwarisan Konghucu itu justru merupakan kekuatan untuk mendorong perkembangan ekonomi yang menakjubkan dari 4 macan Asia. Untuk kasus Korea, perkembangan ekonomi itu justru dimotori oleh tradisi. ${ }^{11}$ Dengan demikian, warisan-warisan Konghucu dapat tetap relevan untuk masa yang akan datang.

\section{Transformasi Masa Depan}

Untuk masa yang akan datang, ada kemungkinan bahwa Konghucu dapat berkembang sehingga dapat menyebarkan ajarannya kepenjuru dunia, meskipun Faham Konghucu tidak pernah menjadi agama yang terorganisasi. ${ }^{12}$

Seiring dengan perkembangan zaman, Faham Konghucu tidaklah menjadi bebas untuk menyatukan agama dunia di masa depan, tetapi Konghucu dengan ajaran moral yang humanis dapat menjadi pusat untuk menyatukan beberapa agama dan ideologi tanpa menimbulkan konflik dengan kepercayaan mereka secara esensial. Konghucu dapat

aspek keagamaan dan sosial. Apabila sikap setiap orang sesuai dengan statusnya yaitu hendaknya ayah tetap ayah, anak tetap anak, raja tetap raja, hamba tetap hamba, maka akan lahir kesadaran akan "hak" dan "kewajiban". Sistem kekerabatan harus didasarkan pada syian, yaitu suatu perasaan keterikatan terhadap orang -orang yang menurunkannya. Asmoro Achmadi, Filsafat Umum, (Jakarta: PT RajaGrafindo Persada dengan bekerjasama dengan Badan Penerbitan IAIN Walisongo Press, 2000), h. 91.

${ }^{11}$ Asmoro Achmadi, Filsafat Umum, h. 200-201. Perkembangan dikatakan sukses itu untuk inovasi yang terstuktur dan terorganisasi yang menerapkan mobilisasi manusia dan sumber-sumber material, aspek luar dan dalam saling mendukung suksesnya program tersebut, dan untuk budaya yang bersatu padu saling mendukung. Banyak dari karakteristik Konghucu dapat diinterpretasikan sebagai pendukung dan penghalang modernisasi.

12 Asmoro Achmadi, Filsafat Umum, h. 201. 
mencapai kehidupan baru di dunia yang luas ini, meskipun ada kemungkinan akan kehilangan identitasnya.

Dengan demikian, Konghucu dengan ajarannya yang humanis dapat menyebar ke berbagai negara termasuk ke Indonesia.

\section{Perkembangan Konghucu di Indonesia}

Agama Konghucu mulai berkembang di wilayah Indonesia seiring dengan kedatangan bangsa Tiongkok (Cina). Agama Konghucu tumbuh dan berkembang di tengah-tengah pertumbuhan dan perkembangan agama-agama: Islam, Kristen Protestan, Katolik, Hindu, dan Buddha yang kesemuanya itu bukanlah agama asli dari bumi Indonesia. ${ }^{13}$

Selanjutnya, untuk mengkaji tentang perkembangan Konghucu di Indonesia, terlebih dahulu melihat kehidupan keagamaan yang difokuskan pada perkembangan agama-agama yang ada di Indonesia, termasuk didalamnya kontrofersi seputar pemunculan lima agama resmi (official religions). Maksudnya adalah agar diperoleh gambaran awal tentang perkembangan agama-agama tersebut dan dapat membantu untuk memahami upaya pencapaian hidup yang rukun di tengah komunitas masyarakat yang plural.

Mengenai berbagai macam agama yang tumbuh dan berkembang di Indonesia, perlu untuk menyimak proses pemunculan lima agama resmi yang diakui oleh pemerintah sejak awal Pemerintahan Orde Baru, yaitu: Agama Hindu, Buddha, Islam, Kristen Protestan dan Katolik. Eksistensi kelima agama besar tersebut tertuang dalam Undang-Undang nomor 1/PNPS tahun 1965 yang merupakan penguat dari Penetapan Presiden nomor 1 tahun $1965 .^{14}$

Sebagaimana yang kita ketahui bahwa sebelum munculnya Undang-Undang tersebut, secara historis di Indonesia telah ada sebuah agama yang memiliki jumlah pengikut yang tidak bisa dibilang kecil, yaitu Agama Konghucu (Konfusianisme). Bahkan hasil sensus penduduk tahun 1971 menunjukkan bahwa penganut agama ini berjumlah hampir

${ }^{13}$ Hs. Tjhie Tjay Ing dan Ks. Chandra Setiawan, "Paradigma Sejarah dan Perkembangan Agama Konghucu", makalah dipresentasikan dalam Seminar Nasional, diselenggarakan oleh HMJ Fak. Ushuluddin IAIN Sunan Ampel Surabaya, 15 November 1997, h.1.

${ }^{14}$ M. Arifin, Menyingkeap Metode-metode Penyebaran Agama di Indonesia (Jakarta: Golden Terayon Press, 1990), h.4. 
satu juta orang. ${ }^{15}$ Banyak kalangan menilai bahwa "penghapusan" agama Konghucu dan kemudian menempatkannya hanya sebagai suatu "ajaran etika" memiliki keterkaitan dengan kepentingan politik sebagai ekses dari munculnya Gerakan 30 September PKI pada tahun $1965 .{ }^{16}$ Kehadiran Undang-Undang tersebut pada akhirnya memunculkan konversi besarbesaran penganut Konghucu kedalam agama Kristen. ${ }^{17}$

Kontroversi lain tentang kebijakan pemerintah yang berkaitan dengan pemantapan eksistensi kelima agama resmi diatas adalah dikeluarkannya Instruksi Menteri Agama RI nomor 4 tahun 1978 tentang kebijaksanaan mengenai aliran-aliran kepercayaan sebagai pelaksanaan terhadap ketetapan MPR nomor IV/MPR/1978 tentang GBHN yang antara lain menyatakan bahwa aliran kepercayaan terhadap Tuhan Yang Maha Esa tidak merupakan agama. ${ }^{18}$ Kenyataan ini tentunya memunculkan reaksi keras di masyarakat, khususnya dari penganut aliran kepercayaan yang mayoritas berasal dari kalangan abangan. ${ }^{19}$

Dengan mendasarkan pada kedua kebijakan pemerintah diatas, bisa dikatakan bahwa agama yang ada di Indonesia dibedakan menjadi dua kategori, yaitu:

1. Official Religion, yaitu agama yang memperoleh pengakuan (legitimasi) dari pemerintah untuk hidup dan berkembang di Indonesia. Agama yang termasuk dalam kategori ini adalah: Hindu, Budha, Islam, Kristen Protestan, dan Katolik.

2. Non-official Religion, yaitu agama selain kelima agama diatas yang terdapat di Indonesia, namun oleh pemerintah tidak dianggap sebagai agama tersendiri, tetapi dipandang sebagai aliran atau cabang dari kelima

${ }^{15}$ Hasil sensus penduduk bulan september tahun 1971 menunjukkan bahwa penganut agama Konghucu sebanyak 972.133 orang. Sumber Data Biro Pusat Statistik "Sensus Penduduk September 1971".

${ }^{16}$ Th. Sumartana, "Konfusianisme di Indonesia" dalam Th. Sumartana, dkk., Konfusianisme di Indonesia: Pergulatan Mencari Jati Diri (Yogyakarta: DIAN/Interfidei, 1995), h. Xviii-xix.

${ }^{17}$ Abdurrahman Wahid, "Konfusianisme di Indonesia: Sebuah Pengantar", dalam Ibid., h.xxxii.

18Zaini Ahmad Noeh, Pedoman Dasar Kerukunan Hidup Beragama (Jakarta: Proyek Pembinaan Kerukunan Hidup Beragama Departemen Agama RI, 1979), h.8182.

${ }^{19}$ Keterangan lebih lanjut tentang berbagai macam aliran kepercayaan, lihat: Rahmat Subagya, Aliran Kepercayaan dalam Sorotan (Jakarta: BPK Gunung Mulia, 1997). 
agama diatas, seperti: Konghucu, aliran kepercayaan (kebatinan), dan lain-lain. ${ }^{20}$

Pembedaan agama kedalam dua kategori seperti diatas sebenarnya tidak lepas dari realitas jumlah penduduk suatu agama yang ada di Indonesia, disamping juga adanya perbedaan tentang konsep agama itu sendiri.

Ciri-ciri dari suatu ajaran bisa disebut sebagai agama di Indonesia haruslah:

1. Mengakui adanya Tuhan Yang Maha Esa.

2. Mempunyai rasul atau nabi.

3. Mempunyai kitab suci.

4. Mempunyai hukum tersendiri untuk membimbing kebahagiaan hidup penganutnya.

5. Tujuan terakhir dari hukum-hukum itu adalah untuk mencapai keharmonisan hidup dalam dunia ini dan kebahagiaan hakiki dan abadi di akhirat nanti. ${ }^{21}$

Dengan berbagai macam peraturan kenegaraan yang ada, eksistensi kelima agama resmi semakin mantap dan kenyataan dalam masyarakat menunjukkan bahwa kelima agama tersebutlah yang mengalami perkembangan yang cukup signifikan. ${ }^{22}$

Pada masa pemerintahan Orde Baru di Indonesia, agama Konghucu dipandang bukan sebagai agama tetapi hanya salah satu cabang dari agama Buddha. Pemerintahan Orde Baru menciptakan berbagai pandangan negatif tentang agama Konghucu, seperti klaim bahwa agama Konghucu sebagai aliran sesat, penghambat proses

${ }^{20}$ Penegasan bahwa aliran kebatinan bukan merupakan agama tercermin dari Amanat Meneteri Agama Prof. Dr. H. A. Mukti Ali pada tanggal 16 Februari 1972: "Pemerintah tidak melarang adanya aliran-aliran yang menuntun warganya kearah pematangan jiwa dan keluhuran budi. Namun perlu disadari bahwa aliran-aliran kepercayaan yang beratus-ratus jumlahnya di Indonesia bukan agama". Adapun Konghucu dipandang sebagai bagian dari agama Budha.

${ }^{21}$ M. Noor Matdawam, Pembinaan Aqidah Islamiyah (Yogyakarta: Yayasan Bina Karier LP5BIP, 1984), h.2-3.

${ }^{22}$ Meskipun dengan tumbangnya pemerintahan Orde Baru, mulai muncul kembali berbagai kelompok keagamaan, terutama dari penganut Konghucu, namun dominasi kelima agama resmi tersebut masih sangat kuat. Hal ini dipertegas dengan belum adanya wadah organisasi keagamaan diluar kelima agama tersebut yang mendapat pengakuan secara formal dari pemerintah melalui Departemen Agama. 
asimilasi, bersifat eksklusif, feodal, dan sebagainya. ${ }^{23}$ Sehingga, dapat dipahami bahwa selama masa pemerintahan Orde Baru di Indonesia, perayaan Imlek menjadi aktivitas yang terlarang.

Perayaan Imlek itu merupakan bentuk budaya Cina, termasuk didalamnya agama Konghucu. Kalau ditelusuri sejarahnya, perayaan Imlek atau Sin Tjia merupakan perayaan yang dilaksanakan oleh petani di Cina. Perayaan Imlek dilaksanakan untuk memperingati tahun baru dan datangnya musim semi. Berdasarkan kenyataan ini, hampir semua bentuk persembahan pada perayaan Imlek adalah makanan. Biasanya makananmakanan yang dijadikan persembahan melambangkan kebahagiaan, keselamatan, panjang umur, dan sebagainya. Pada malam menjelang pergantian tahun, mereka biasanya makan dirumah atau restoran kemudian mereka berjaga sepanjang malam dan membuka pintu rumah mereka lebar-lebar dengan harapan bahwa rejeki akan memasuki rumah mereka. Sebagai pelengkap perayaan Imlek, atraksi barongsai menjadi rangkaian peristiwa perayaan Imlek yang paling menarik bagi masyarakat. ${ }^{24}$ Selama masa Pemerintahan Orde Baru di Indonesia, perayaan Imlek tersebut menjadi aktivitas yang terlarang.

Seiring dengan tumbangnya pemerintahan Orde Baru, wacana terhadap agama resmi kembali menjadi sorotan. Berbagai kalangan menilai perlunya mengkaji ulang kebijakan berkenaan dengan kebebasan beragama. Hal ini telah mendorong dicabutnya berbagai kebijakan yang melarang segala bentuk Budaya Cina, termasuk didalamnya Agama Konghucu, yang telah diterapkan selama kurun waktu pemerintahan Orde Baru. Dengan mendasarkan pada kenyataan ini, pembahasan tentang agama-agama di Indonesia tidak hanya dibatasi pada kelima agama resmi, yaitu: Agama Hindu, Budha, Islam, Kristen Protestan dan Katolik, tetapi juga Agama Konghucu mengingat mayoritas warga negara keturunan etnis Cina memeluk agama ini.

Dengan tumbangnya rezim Orde Baru tersebut, pemeluk Agama Konghucu mendapatkan kembali kebebasan mereka untuk mengekspresikan segala aktivitas keagamaan mereka. Pada bulan Febuari 2000, perayaan Imlek pertamakali diadakan secara terbuka. Berbagai

${ }^{23}$ Tjandra L. Muljadi, "Umat Konghucu Indonesia dalam Bayang-bayang Keadilan”, dalam J. Dwi Hely Purnomo (ed.), Hak Asasi Beragama dan Perkawinan Konghucu (Jakarta: Gramedia, 1998), h.85.

${ }^{24}$ Suwandi HS., "Imlek di Indonesia", dalam: http:// www.seasite.niu.edu/indonesia/budaya-bangsa/pecinan/imlek.htm. 
macam atraksi, terutama liong dan barongsai mulai diadakan kembali secara terbuka untuk menyambut perayaan Imlek. Salah satu hal yang menarik dalam pelaksanaan atraksi tersebut adalah latar belakang para pemainnya yang berasal dari berbagai agama, seperti Buddha, Islam, dan Kristen. ${ }^{25}$ Berdasar realitas diatas, perayaan Imlek bisa dijadikan sebagai sarana untuk menggalang persaudaraan di antara anggota masyarakat.

Selain atraksi tersebut, di daerah-daerah pedesaan, perayaan Imlek sebagaimana perayaan hari besar keagamaan lainnya, juga ditandai dengan saling kunjung-mengunjungi diantara warga masyarakat untuk saling mendo'akan dan meminta maaf. Pada perayaan Imlek tahun 2003 muncul fenomena menarik yaitu permintaan dari komunitas Cina Muslim (Persatuan Islam Tionghoa atau PITI) kepada Majelis Ulama Indonesia untuk melaksanakan perayaan Imlek di masjid-masjid. ${ }^{26}$ Apabila permintaan ini diperbolehkan oleh MUI, tentunya akan menjadi sarana yang baik dalam memupuk rasa persaudaraan di antara anggota masyarakat.

Kalau ditelusuri sampai saat ini, perayaan Imlek akan tetap ada dan meriah di indonesia. Pada perayaan itu, pemerintah telah memberikan perhatian dengan meliburkan hari Perayaan Imlek tersebut. Meskipun masih satu bulan lagi, daerah Pecinan Solo telah disibukkan oleh persiapan perayaan tersebut. Masyarakat telah banyak yang mengunjungi toko-toko untuk membeli persiapkan perayaan tersebut. Salah satu toko yang bernama Apple Collection \% Florish telah ramai dikunjungi tamu untuk membeli mac-am lampion, angpau mercon renteng, patung, uang-uang emas dan sampi coklat, ${ }^{27}$ meskipun Tahun Baru Imlek 2556 itu masih 4 minggu lebih yaitu pada hari Rabu tanggal 9 Februari 2005 nanti.

Dengan mendasarkan pada realitas pelaksanaan perayaan imlek diatas, bisa dikatakan bahwa kehidupan rakyat Indonesia tidak bisa dilepaskan dari fenomena keagamaan yang terjadi di masyarakat. Seringkali nilai-nilai universal yang terkandung dalam perayaan hari besar keagamaan menjadi suatu pegangan manusia tidak hanya saat berhadapan dengan permasalahan-permasalahan keagamaan saja, tetapi juga untuk mengatasi berbagai permasalahan sosial yang sedang di hadapi oleh

\footnotetext{
25Johny Tg., "Imlek Dirayakan secara Terbuka", dalam: http:/ / wmw.kompas.com/kompas-cetak/0002/06/ utama/ imlek01.htm.

${ }^{26}$ Jogja Metropolis, 1 Februari 2003, h.1.

${ }^{27}$ Lihat artikel "Siap Sambut Imlek", Radar Jogya, Selasa, 11 Januari 2005, h.8.
} 
masyarakat. Oleh karenanya, perayaan hari besar keagamaan memainkan peranan penting dalam memelihara nilai-nilai sosial masyarakat.

Dengan demikian, meskipun perkembangan agama Konghucu mengalami berbagai hambatan pada masa pemerintahan Orde Baru, eksistensi agama Konghucu masih bertahan hingga saat ini khususnya di Indonesia.

\section{Toleransi dalam Agama Konghucu}

Terlepas dari masalah perkembangan Agama Konghucu, salah satu hal penting yang harus diperhatikan berkenaan dengan kehidupan sosial adalah masalah ajaran Agama Konghucu, terutama berkenaan dengan ajaran toleransi. Sebagaimana ajaran Agama-agama Timur lainnya yang menekankan pada masalah etika, ajaran Agama Konghucu memiliki tujuan untuk menegakkan pemerintah dalam masyarakat dengan cara meluruskan cara berpikir baik bagi yang memerintah maupun rakyat; disamping atas dasar pembangunan watak yang bertaqwa kepada Tuhan, memenuhi kewajiban sosial dan dengan pemerintahan yang bersih. ${ }^{28}$

Secara ringkas bisa disebutkan bahwa dasar-dasar ajaran toleransi dalam Agama Konghucu tercermin dari berbagai ajarannya tentang etika. Konsep etika dalam Ajaran Agama Konghucu secara garis besar terdiri dari ajaran: ngo siang (lima kebajikan), pat tik (delapan kebajikan), dan ngo lun (lima hubungan kemanusiaan).

Ngo Siang itu terdiri dari ajaran tentang jen (kemanusiaan), li (tata krama), I (kelayakan), dan hsiao (bakti kepada orang tua). Pat Tik terdiri dari hau (laku bakti), tee (rendah hati), tiong (setia), sien (dapat dipercaya) lee (susila), gi (laku benar), lhiam (sucihati), dan thi (tahu malu).

Sedangkan Ngo lun itu terdiri dari hubungan antara pemegang pucuk pemerintahan dengan para menteri, ayah dengan anak, suami dengan isteri dan kakek, serta hubungan antara teman dengan teman. Untuk menegakkan ngo Iun ini para pemeluk Agama Konghucu senantiasa berpegang pada sepuluh kewajiban, yaitu: orang tua berlaku kasih sayang, anak berlaku bakti, kakak berlaku baik hati, adik berlaku rendah hati, suami berlaku benar, isteri mau mendengar, yang tua

${ }^{28}$ Kosasih Atmowardoyo, "Pengaruh Konfusianisme Pada Perilaku Berekonomi Etnis Cina", dalam Th. Sumartana, dkk. (ed.), Konfusianisme di Indonesia: Pergulatan Mencari Jati Diri (Yogyakarta: INTERFIDEI, 1995), h.57. 
bermurah hati, yang muda mengikuti, pemimpin bersifat cinta kasih, dan menteri bersifat setia. ${ }^{29}$

Selain konsep tentang etika tersebut, Teologi Konghucu juga memberikan tempat bagi kebebasan beragama, dengan memberikan pengertian agama itu secara universal sebagai berikut, "Firman Thian (Tuhan YME) itulah yang dinamai Watak Sejati. Hidup mengikuti Watak Sejati itulah yang dinamai menempuh Jalan Suci. Bimbingan menempuh Jalan Suci itulah yang dinamai agama". Pada ayat lain dikatakan, "Kalau berlainan Jalan Suci tidak usah berdebat". ${ }^{30}$ Dengan demikian jelaslah bahwa Ajaran Agama Konghucu memberikan jaminan akan pelaksanaan toleransi terhadap eksistensi agama lain.

Dengan memperhatikan uraian tentang toleransi diatas, setidaknya ada dua hal yang perlu mendapatkan perhatian serius dari masing-masing pihak agar toleransi bisa dikembangkan kearah yang lebih baik bagi kehidupan bersama. Pertama, berkenaan dengan definisi toleransi itu sendiri. Hal ini sangat penting untuk dilakukan dalam konteks masyarakat Indonesia mengingat selama ini belum ada kesepakatan bersama tentang definisi dan batas-batas toleransi yang boleh dan harus dikembangkan oleh masing-masing pihak. Dalam hal ini mungkin Umat Islam lebih memerlukan kejelasan tersebut mengingat Ajaran Agama Islam dengan tegas melarang adanya kerjasama dengan agama lain dalam hal peribadatan. Terlebih lagi realitas pelaksanaan toleransi agama selama ini cenderung mengarah kepada suatu bentuk penyembunyian identitas-identitas maupun simbol-simbol keagamaan yang semestinya harus ditonjolkan agar bisa dipahami dan dimengerti oleh pemeluk agama lain. Kedua, berkenaan dengan komitmen dalam mengaplikasikan ajaran-ajaran toleransi agama dalam kehidupan seharihari. Hal ini juga perlu mendapat perhatian serius dari masing-masing pihak mengingat ada kecenderungan berkembangnya sekte-sekte atau kelompok-kelompok fundamentalis dari masing-masing agama yang masih berpegang pada penafsiran doktrin secara harfiah (tekstual) yang sedikit banyak akan berpengaruh negatif terhadap pengembangan sikap toleransi di masyarakat.

${ }^{29}$ Lasiyo, "Ajaran Konfusianisme Tinjauan Sejarah dan Filsafat”, dalam Th. Sumartana, dkk. (ed.), Konfusianisme di Indonesia: Pergulatan Mencari Jati Diri (Yogyakarta: INTERFIDEI, 1995), h.22.

${ }^{30}$ Chandra Setiawan, "Peranan Warga Negara dan Negara, h.36. 
Pengembangan sikap toleransi agama ini tidak bisa dilepaskan dari bagaimana masyarakat memahami serta mensikapi masalah pluralisme agama yang ada di masyarakat sebagai konsekuensi logis dari pertemuan berbagai macam agama yang memiliki ciri dan ajarannya tersendiri.

Dengan demikian, Konghucu di Indonesia mempunyai kemiripan dengan yang ada di Korea. Dimana meskipun minoritas, mereka mempunyai kekuatan spiritual yang dapat merangkul beberapa agama. Seperti perayaan Imlek ternyata melibatkan agama lain seperti Budha, Hindhu, Kristen dalam pementasan barongsai. Konghucu dengan Ajaran Konghucu ternyata ikut memberi perhatian terhadap kerukunan hidup beragama dan ini merupakan modal awal untuk memperkuat tali persaudaraan antar umat beragama.

\section{Penutup}

Berdasarkan paparan diatas dapat disimpulkan bahwa: Pertama, Konghucu yang secara statistik minoritas ternyata setelah melalui penelitian yang mendalam, menjadi ideologi yang mendominasi Korea. Pelajaran dalam pembahasan ini yang dapat diambil adalah cara untuk meneliti sebuah ajaran dengan menggunakan metode identifikasi konfensional. Dengan metode ini, ternyata menghasilkan gambaran yang berbeda tentang seputar puncak agama. Metode yang langkahnya adalah dengan melakukan wawancara terhadap orang satu persatu dengan menyodorkan beberapa pertanyaan tentang keyakinan dan praktek Konghucu di masyarakat itu ternyata mampu menguak secara mendalam realitas yang berkembang dalam masyarakat. Pendekatan ini ternyata dapat sebagai salah satu metode yang dapat digunakan oleh beberapa peneliti lain untuk mengkaji fenomena yang ada di masyarakat terutama yang berhubungan dengan praktek keagamaan di masyarakat.

Kedua, dengan Ajaran Konghucu yang mengutamakan moralitas, toleransi, tidak terorganisir dan tidak misionar dapat merangkul beberapa pemeluk agama lain untuk menerapkan ajarannya. Ketiga, sesuai dengan perkembangan zaman, disamping dipandang sebagai penghambat modernisasi, ternyata justru dari tradisi mereka dapat sebagai pendorong untuk maju, khususnya dalam perkembangan ekonomi. Keempat, di Indonesia, Konghucu mengalami perkembangan, dimana pada masa Pemerintahan Orde Baru, Konghucu tidak dianggap sebagai agama dan perayaan Imlekpun dilarang. Setelah Orde Baru, Konghucu diperbolehkan. Dalam prakteknya, Konghucu di Indonesia mempunyai 
kemiripan dengan yang ada di Korea. Meskipun minoritas, mereka mempunyai kekuatan spiritual yang dapat merangkul beberapa agama. Seperti Perayaan Imlek yang merupakan Budaya Cina yang mayoritas beragama Konghucu itu ternyata melibatkan agama lain seperti Budha, Hindhu, Kristen dalam pementasan barongsai. Kelima, Konghucu dengan ajarannya ternyata mendukung adanya kerukunan hidup beragama dan ini merupakan modal awal untuk memperkuat tali persaudaraan antar umat beragama. Kedepannya, Konghucu dapat sebagai salah satu wahana untuk menyatukan beberapa agama dalam menghadapi persoalan khususnya dalam dan antar agama, tanpa kehilangan jati dirinya sebagai ajaran.

\section{DAFTAR PUSTAKA}

Achmadi, Asmoro. Filsafat Umum, Jakarta: PT RajaGrafindo Persada dengan bekerjasama dengan badan Penerbitan IAIN Walisongo Press, 2000

Arifin, M. Menyingkap Metode-metode Penyebaran Agama di Indonesia Jakarta: Golden Terayon Press, 1990.

Atmowardoyo, Kosasih. "Pengaruh Konfusianisme Pada Perilaku Berekonomi Etnis Cina", dalam Th. Sumartana, dkk. (ed.), Konfusianisme di Indonesia: Pergulatan Mencari Jati Diri Yogyakarta: INTERFIDEI, 1995.

Byong-ik , Koh. "Confucianism in Korea Kontemporer", dalam Tu Wey-Ming (ed) Confusian Traditions in East Asia Modernity : Moral Education and the Four Mini Dragons, Cambridge, Massachusetts, London, England: Harvard University Press, 1996.

Creel, H.G. Alam Pikiran Cina: Sejak Confucius sampai Mao Zedong, diterjemahkan oleh Soejono Soemargono, Yogyakarta: PT Tiara Wacana, 1989.

Hariyono, P. Kultur Cina dan Jawa: Pemahaman Menuju Asimilasi Kultural, Jakarta: Pustaka Sinar Harapan, 1994. 
Lasiyo, "Ajaran Konfusianisme Tinjauan Sejarah dan Filsafat", dalam Th. Sumartana, dkk. (ed.), Konfusianisme di Indonesia: Pergulatan Mencari Jati Diri,Yogyakarta: INTERFIDEI, 1995.

Matdawam, M. Noor. Pembinaan Aqidah Islamiyah, Yogyakarta: Yayasan Bina Karier LP5BIP, 1984.

Muljadi, Tjandra L. "Umat Konghucu Indonesia dalam Bayang-bayang Keadilan", dalam J. Dwi Hely Purnomo (ed.), Hak Asasi Beragama dan Perkawinan Konghucu Jakarta: Gramedia, 1998.

Noeh, Zaini Ahmad. Pedoman Dasar Kerukunan Hidup Beragama, Jakarta: Proyek Pembinaan Kerukunan Hidup Beragama Departemen Agama RI, 1979.

Setiawan, Chandra "Peranan Warga Negara dan Negara dalam Pelaksanaan dan Perlindungan HAM: Tinjauan Teologi Konghucu", dalam J. Dwi Hely Purnomo (ed.), Hak Asasi Beragama dan Perkawinan Konghucu, Jakarta: Gramedia, 1998.

Subagya, Rahmat. Aliran Kepercayaan dalam Sorotan, Jakarta: BPK Gunung Mulia, 1997

Sumartana, Th. "Konfusianisme di Indonesia" dalam Th. Sumartana, dkk., Konfusianisme di Indonesia: Pergulatan Mencari Jati Diri. Yogyakarta: DIAN/Interfidei, 1995.

Titus, Harold H. dan Marilyn S. Smith, serta Richard T.Nolan, Pesoalanpersoalan Filsafat, alih bahasa H.M. Rasjidi, Jakarta, Indonesia: Bulan Bintang, 1984.

Tjay Ing, Hs. Tjhie dan Ks. Chandra Setiawan, "Paradigma Sejarah dan Perkembangan Agama Konghucu", makalah dipresentasikan dalam Seminar Nasional, diselenggarakan oleh HMJ Fak. Ushuluddin IAIN Sunan Ampel Surabaya, 15 November 1997.

Wahid, Abdurrahman. "Konfusianisme di Indonesia: Sebuah Pengantar", dalam Th. Sumartana, dkk., Konfusianisme di Indonesia: Pergulatan Mencari Jati Diri, Yogyakarta: DIAN/Interfidei, 1995. 